\title{
Skint: Retirement? Financial Hardship and Retirement Planning Behaviors
}

\author{
Lu Fan ${ }^{1} \cdot$ Richard Stebbins $^{2} \cdot$ Kyoung Tae Kim ${ }^{3}$ (1)
}

Accepted: 23 June 2021 / Published online: 3 July 2021

( ) The Author(s), under exclusive licence to Springer Science+Business Media, LLC, part of Springer Nature 2021

\begin{abstract}
This study used data from the 2018 National Financial Capability Study to investigate the association between financial hardship and retirement planning behaviors. Results from logistic regressions showed that respondents with high difficulty making ends meet were more likely to calculate retirement needs and more likely to own a non-employer sponsored retirement plan. The perceived over-indebtedness was positively associated with owning an employer-sponsored account while negatively associated with owning a non-employer-sponsored account. Financial fragility was associated with a lower likelihood of calculating retirement needs and having a retirement account. The results of additional generational analyses revealed that the difficulty making ends meet and the perceived over-indebtedness showed different patterns with retirement planning behavior across three generations. In contrast, financial fragility showed consistent and negative associations with the retirement planning behaviors across generations.
\end{abstract}

Keywords Retirement planning · Financial hardship · Retirement saving · Financial fragility · Financial knowledge

JEL classification D14 · G5

\section{Introduction}

Families going through financial hardship often struggle with monthly bills, feel they have too much debt, and do not have emergency funds. Planning for retirement is a challenge for families with financial hardships. Retirement planning is a financial goal that demands increasing individual responsibility due to the reduction or loss of guaranteed income

Kyoung Tae Kim

ktkim@ches.ua.edu

Lu Fan

fanlu@missouri.edu

Richard Stebbins

rstebbins@ches.ua.edu

1 Department of Personal Financial Planning, University of Missouri, 239 Stanley Hall, Columbia, MO 65211, USA

2 Department of Consumer Sciences, University of Alabama, 316-E Adams Hall, Box 870158, Tuscaloosa, AL 35487, USA

3 Department of Consumer Sciences, University of Alabama, 316-C Adams Hall, Box 870158, Tuscaloosa, AL 35487, USA streams. Social Security benefits represented 33\% of income for the 48 million Americans receiving retirement benefits in 2020 (Social Security, 2020). In 2035, 78 million Americans will be over age 65 , and the Social Security reserve fund will be depleted, causing benefits to be reduced (Social Security, 2020). Defined contribution (DC) plans have replaced defined benefit (DB) plans. In 2020, only $25 \%$ of Americans had access to a DB plan (Bureau of Labor Statistics, 2020), and less than half of those DB plans were covered by the Pension Benefit Guaranty Corporation (PBGC, 2019). However, $60 \%$ of Americans have access to a DC plan (Bureau of Labor Statistics, 2020).

The annual poverty rate in the United States was $10.5 \%$ in 2019 (Semega et al., 2020) and peaked at 17.3\% in September 2020 during the global COVID-19 pandemic (Parolin et al., 2020). Retirement savings and planning can be a salient issue, especially for those who had furloughed or laid off due to the pandemic. The Coronavirus, Aid, Relief, and Economic Security (CARES) Act adjusted loan borrowing terms from 401(k)s, to ease financial burdens, at the cost of future retirement account accumulations. Nationwide, the United States Census Bureau expects $35.6 \%$ of adults to have difficulty paying usual household expenses, $35.3 \%$ to be behind 
on rent or mortgage, and $31 \%$ of adults to expect someone in their house to have a loss in employment income in the next month (U.S. Census Bureau, 2020). Understanding the relationship between financial hardship and retirement planning is key for the long-term well-being of US households.

It has been documented in the literature that household financial and economic hardship can be significantly associated with financial behavior and well-being. For example, Gjertson (2016) suggested a close relationship between emergency savings and household economic hardship. Baek and DeVaney (2010) found that utilizations of credit and savings were the two primary methods to cope with household economic hardship. Park et al. (2017) found that financial hardship could indirectly and negatively relate to mental distress. Moreover, family financial hardship can also have negative influences on children. Parents experiencing economic hardship could also trigger mental distress of children in high school (Lempers et al., 1989), and such effect can last when children grow into adulthood (Sobolewski \& Amato, 2005). However, the association between financial hardship status and retirement planning behavior has been understudied relatively.

This study investigates the relationship between financial hardship and retirement planning behaviors of US workers. We particularly examined the role of financial hardship on retirement planning proxied by calculating retirement needs and having a retirement account. Financial hardship was examined using three measures; (a) making ends meet, (b) perceived over-indebtedness, and (c) financial fragility. Similar analyses were conducted across subsamples of three generations, Millennials, Generation X, and Baby Boomers to examine generational differences and for the robustness check of our results. The findings make an important contribution to the field of retirement planning behavior from a financial hardship perspective and provide practical and policy implications.

\section{Review of Literature}

\section{Retirement Planning Behavior}

The life cycle hypothesis is an economic theory that assumes households take future income into account when planning lifetime spending (Ando \& Modigliani, 1963). According to the life cycle hypothesis, individuals seek to smooth lifetime consumption by borrowing, saving, and dissaving (Ando \& Modigliani, 1963). To do so, households borrow when young, save for retirement during the earning years, and then spend those dollars in retirement (Ando \& Modigliani, 1963). This smooth pattern of consumption can be measured as expenditures on nondurable goods, services, nonauto durables, and durable goods (Poterba, 2000). In order to maintain a stable level of consumption throughout a lifetime, the amount saved for retirement should be lower for those with pension plans and access to Social Security benefits. Savings invested in a retirement account to dissave in retirement can differ in households with children and the culture also may influence whether that impact is positive or negative (Modigliani \& Cao, 2004).

Households planning for retirement should consider when they plan to retire, how long they expect retirement to last, and how they envision life in retirement. It is also important to understand income sources during retirement; Social Security benefits are a significant income source for retirees (Dushi et al., 2017). Those with lower earnings are more likely to file early and receive a reduced Social Security benefit (Gillen \& Heath, 2014). These considerations allow for calculating retirement needs and an optimal savings rate required to reach that goal; however, most people use heuristics rather than calculations (Bernartzi \& Thaler, 2007). The pre-retirement savings rate decisions, if considered, are often too low and result in a savings shortfall or a delay in retirement (Romm, 2015). A withdrawal rate should also be calculated to ensure funds will not be depleted during retirement (Bengen, 1994; Pfau, 2011).

Retirement planning behavior is influenced by many factors, including financial knowledge, education, income, age, and even financial sophistication (Hira et al. 2009; van Rooij et al., 2012; Kim \& Hanna, 2015). Generational differences have also been examined. Given the shift from defined benefit plans to defined contribution plans (Bureau of Labor Statistics, 2020), it is not surprising that only $8.9 \%$ of working Millennials have a defined benefit plan (Yao \& Cheng, 2017). In addition, $74 \%$ of Millennials believe that Social Security benefits will not be available at retirement (Wells Fargo, 2016). This places more onus on Millennials to plan for retirement, yet Millennials prefer a higher salary and weaker retirement benefits while Baby Boomers prefer a lower salary and stronger retirement benefits (Wells Fargo, 2016). Despite that preference for stronger retirement benefits, Baby Boomers also expect to continue working past Social Security retirement benefit eligibility (Dong et al., 2017). Generation Xers and younger Baby Boomers have a similar risk of being unable to smooth consumption in retirement at 57\% and 50\%, respectively, while older Baby Boomers have a 37\% risk (Munnell et al., 2006). The breadth of research highlights the importance. Here we focus on two aspects of retirement planning; calculating retirement needs and retirement account ownership.

Calculating retirement needs can be complicated and challenging due to anxiety created by market volatility (Sharpe, 2020). Less than half of U.S. households attempt to calculate retirement needs; however, $77 \%$ of workers are confident that they will have a comfortable retirement (EBRI, 2020). Those with higher financial literacy levels are 
more likely to have calculated retirement needs (Lusardi \& Mitchell, 2017). Confidence in a comfortable retirement is closely related to owning a retirement plan (EBRI, 2020). $60 \%$ of Americans have access to a defined contribution retirement plan (Bureau of Labor Statistics, 2020).

\section{Financial Hardship}

There has not been a consistent definition of household financial hardship. This concept is often interchangeably used with economic hardship, which can be defined as "a lack of the money needed to meet family needs for food, clothing, shelter, and medical care" (Mirowsky \& Ross, 1999, p. 549). An acute financial hardship, such as the family car breaking down and needing repair, can have a temporary negative impact on the family's budget. If a family does not have an emergency fund, recovery can take longer. A chronic financial hardship, such as ongoing medical care for a family member with a disability, can have a lifelong negative impact on the family budget. Financial hardship is comprised of three factors in this study: (a) the ability to meet monthly expenses, (b) perceived over-indebtedness, and (c) financial fragility. Financial hardship can be conceptualized with both objective and subjective measures, including, for example, inability to make ends meet (difficulty covering monthly expenses), high debt, and material hardship (Short, 2003). Other financial hardship indicators include delaying paying off bills, rent, or mortgages (Gjertson, 2016). Financial challenges influence more stress than jobs, relationships, health concerns, or any other stressor (PwC, 2020). Financial hardship is found to have a positive role in holding negative perceptions of the current financial situation and perceived stress level among middle-aged US adults (Park et al., 2017).

In 2018, half of Americans had some difficulty making ends meet, and 55\% of Americans spent all or over their current income (FINRA, 2018). Saving for the future is difficult when necessary spending consumes or exceeds current income (Schreiner \& Sharraden, 2007). The ability to make ends meet is considered an essential element of financial capability; however, about half of US adults reported failing to do so (Lusardi, 2011). Using the 2009 TNS Global Economic Crisis survey, Lusardi and colleagues (2011) used the confidence to come up with $\$ 2000$ in 30 days as a measure for financial fragility and found that a large decrease in wealth can be related to financial fragility. Similar evidence that financial fragility is a pervasive national issue was found in a recent study using the 2015 National Financial Capability Study and the 2015 Survey of Household Economics and Decision-making with comparable measures of financial fragility pervasive nationally (Hasler et al., 2018).

While the life cycle hypothesis suggests consumers should borrow to smooth consumption, there are recommended debt ratios (Consumer Financial Protection Bureau, 2019; Experian, 2021). Consumers may have a good reason for violating the prescriptive ratios, so over-indebtedness can also be gauged through the consumer's subjective perception of their debt levels (Tufano \& Lusardi, 2009). Over-indebtedness may mediate relationships between poverty, income, and mental health issues (Fitch et al., 2011). As a subjective measure, $37 \%$ of Americans feel they have too much debt right now (Hasler et al., 2018). Student loan debt is also associated with difficulty in saving for retirement (Hiltonsmith, 2013). Much of this is felt by Millennials, with student loan debt being more common among the younger respondents (Ciluffo, 2017). However, more than half of borrowers across the generations report that student loans have a moderate to significant impact on other financial goals (PwC, 2020). Debt is also associated with declines in mental and physical health (Kim \& Chatterjee, 2019). Long-term debtors (i.e., student loan, mortgage, or car loan borrowers) could be more vulnerable to make ends meet which may be associated with financial distress (de Bassa Scheresberg et al., 2014).

Financial fragility has been measured as a ratio with borrowers with low wealth relative to the cost of a business investment (Bernanke \& Gertler, 1990), and more recently, as an emergency fund of specific dollar amounts (Babiarz \& Robb, 2014; Hasler et al., 2018). One such measure of financial fragility is the ability to immediately come up with $\$ 400$ to cover an emergency expense, and this has been studied alongside the ability to come up with $\$ 2000$ within the next month (Hasler et al., 2018). According to data from Pew Trusts, $60 \%$ of U.S. households experienced a financial shock with a median cost of $\$ 2000$ in the prior year (Pew, 2017). $53 \%$ of those households struggled to make ends meet after the event and younger generations were more likely to struggle than older generations (Pew, 2017). Having an emergency fund reduces the potential difficulty of covering housing, food, clothing, and medical expenses (Despard et al., 2018). Data from the NFCS suggest that subjective financial knowledge, confidence, and owning a savings account are significant predictors of having an emergency fund (Despard et al., 2020). However, building an emergency fund is difficult for some households (Lusardi et al., 2011; Gjertson, 2016), and the difficulty is not limited to those in poverty; $30 \%$ of individuals earning $\$ 50,000-70,000$ are financially fragile, as are $20 \%$ of individuals earning $\$ 75,000-100,000$ (Hasler et al., 2018). More than half of Millennials and Generation X reported that they would take hardship withdrawals from retirement plans (PwC, 2020).

\section{Research Hypotheses}

Based on the literature review, this study constructed two main research hypotheses as follows. 
H1: Experiencing financial hardship is negatively associated with calculating retirement needs.

H1-1: Workers who are having trouble making ends meet are less likely to calculate retirement needs.

H1-2: Workers who perceive themselves as overindebted are less likely to calculate retirement needs. H1-3: Workers who are financially fragile are less likely to calculate retirement needs.

$\mathrm{H} 2$ : Experiencing financial hardship is negatively associated with retirement account ownership.

H2-1: Workers who are having trouble making ends meet are less likely to own a retirement account. H2-2: Workers who perceive themselves as overindebted are less likely to own a retirement account. H2-3: Workers who are financially fragile are less likely to own a retirement account.

\section{Method}

\section{Data and Sample Selection}

This study uses the 2018 state-by-state National Financial Capability Study (NFCS). The NFCS was funded by the FINRA Investor Education Foundation and was conducted online from June through October 2018 with adult participants across the US. The objectives of the NFCS were to collect information about financial capability and individuals' demographic, behavioral, attitudinal, and financial literacy characteristics. Given our study's primary focus, retirement planning behavior, we restricted our analytic sample to workers aged between 25 and 64 . Those younger, older, and retired were excluded because they may behave significantly differently in retirement planning and their overall financial goals may be different (Hasler et al., 2018). Respondents failing to answer the selected variables of this study were dropped from the analyses. The total sample size of 2018 NFCS is 27,091, and our final sample size included 10,748.

\section{Measurement of Variables}

\section{Dependent Variables: Retirement Planning Behaviors}

Two aspects of retirement planning behavior were examined, including calculating retirement needs and owning retirement accounts. In this study, four dependent variables were created as follows. First, respondents were asked, "Have you tried to figure out how much you need to save for retirement?" which was coded as a binary dependent variable. Respondents were also asked whether they had any retirement account(s) through two questions: "Do you (or your spouse/partner) have any retirement plans through a current or previous employer, like a pension plan, a Thrift Savings Plan, or a 401(k)?" and "Do you (or your spouse/ partner) have any other retirement accounts not through an employer, like an IRA, Keogh, SEP, or any other type of retirement account that you have set up yourself?" Answering affirmatively to either question was coded as a binary variable. Finally, we separated employer-sponsored and non-employer-sponsored retirement accounts ownerships into two binary variables for further analysis.

\section{Focal Variables: Financial Hardship}

Three variables were used to measure financial hardship: (a) difficulty making ends meet, (b) perceived over-indebtedness, and (c) financial fragility. Difficulty making ends meet was measured by a question asking, "In a typical month, how difficult is it for you to cover your expenses and pay all your bills?" Three possible responses were "Very difficult," "Somewhat difficult," and "Not at all difficult." Each response was coded as a binary category. Perceived overindebtedness was measured by the respondent's answer to the following statement, "I have too much debt right now", on a 1-7 scale. Lastly, the question "How confident are you that you could come up with $\$ 2000$ if an unexpected need arose within the next month?" was used to measure financial fragility. Levels of 1 to 4 were created based on the possible responses: "I am certain I could come up with the full \$2000", coded as Level 1, "I could probably come up with \$2000" coded as Level 2, "I could probably not come up with \$2000", coded as Level 3, and "I am certain I could not come up with \$2000" coded as Level 4.

\section{Control Variables}

This study included objective and subjective financial knowledge along with socio-demographic characteristics as control variables. The objective financial knowledge variable was constructed using a summated score of six fundamental financial knowledge questions, such as knowledge about inflation, risk, and compounding, with each coded as 1 if answered correctly and 0 if answered incorrectly. Therefore, the objective financial knowledge was on a 0-6 scale, where 0 means the respondent answered all six questions incorrectly, and 6 indicates that all questions were answered correctly. The subjective financial knowledge variable was measured by a self-assessed question on overall financial knowledge, where 1 means very low, and 7 means very high.

We also included socio-demographic characteristics as control variables, including age, gender, race/ethnicity (White, Black, Hispanic, other), education level (high school and lower, some college, college degree, and post-graduate degree), homeowner, income level (\$25,000 and higher, 
$\$ 25,000-\$ 35,000, \$ 35,000-\$ 50,000, \$ 50,000-\$ 75,000$, $\$ 75,000-\$ 100,000, \$ 100,000-\$ 150,000$ and $\$ 75,000$ and higher), married (yes/no), having financially dependent children (yes/no), and working status (working full-time, part-time, and self-employed). We also controlled for the state of residence in the analyses.

\section{Empirical Model Specification}

This study used logistic regression analysis to estimate the relationship between financial hardship and retirement planning. The four retirement planning variables were: (a) calculating retirement needs, (b) owning any retirement account, (c) owning an employer-sponsored retirement account, and (d) owning a non-employer-sponsored retirement account. The logistic regression models can be expressed using

$P\left(R_{i}\right)=\log \left[\frac{P\left(R_{i}\right)}{\left(1-P\left(R_{i}\right)\right.}\right]=\beta_{0}+\mathrm{FH}_{i}^{\prime} \beta_{\mathrm{FH}}+\operatorname{Control}_{i}^{\prime} \beta_{\mathrm{C}}+\varepsilon_{i}$,

where, $P\left(R_{i}\right)$ is the probability of retirement planning for a respondent $\mathrm{i} ; \beta_{0}$ is an intercept; $F H$ denotes the vector of financial hardship variables, including the difficulty of making ends meet, perceived over-indebtedness, and financial fragility; Control variables are objective and subjective financial knowledge, socio-demographic characteristics, and state of residency $\beta_{\mathrm{FH}}$ and $\beta_{\mathrm{C}}$ are the coefficients of these variables and $\varepsilon_{\mathrm{i}}$ is the error term.

\section{Results}

\section{Descriptive Results}

As shown in Table 1, among all the respondents, around $55 \%$ reported having calculated their retirement needs and $79 \%$ had some type of retirement account(s). In particular, $74 \%$ had retirement accounts through an employer and $41 \%$ had non-employer-sponsored retirement accounts. For the financial hardship variables, the proportions of having somewhat difficulty and high difficulty of making ends meet were $35.44 \%$ and $11.36 \%$, respectively. The mean of perceived over-indebtedness was 4.07, on a 1-7 scale. Approximately half of the sample reported the lowest level of financial fragility (49.60\%), followed by 23.88\% (level 2), 12.27\% (level 3), and $14.24 \%$ (level 4 ).

The mean scores of objective and subjective financial knowledge were 3.39 and 5.24. The mean age was about 44 years old. Of all the respondents, $48.40 \%$ were female. $72.67 \%$ were White, $38.54 \%$ had a college degree, and $66 \%$ were homeowners. Moreover, $21.17 \%$ had an annual income of $\$ 50,000-\$ 75,000,57 \%$ were married, $49 \%$ had financially dependent children, and $77 \%$ were employed full-time.
Table 1 Descriptive statistics of analytic sample, 2018 NFCS dataset

\begin{tabular}{|c|c|}
\hline Variable & Mean $(\mathrm{SD}) / \%$ \\
\hline \multicolumn{2}{|l|}{ Retirement planning } \\
\hline Calculating retirement needs & 54.92 \\
\hline Having retirement account (any type) & 78.51 \\
\hline Retirement account (through employer) & 74.25 \\
\hline Retirement account (not through employer) & 40.64 \\
\hline \multicolumn{2}{|l|}{ Difficulty making ends meet } \\
\hline Not difficult & 53.20 \\
\hline Somewhat difficult & 35.44 \\
\hline Very difficult & 11.36 \\
\hline Perceived over-indebtedness (1-7) & $4.07(2.32)$ \\
\hline \multicolumn{2}{|l|}{ Financial fragility } \\
\hline Fragility level 1 & 49.60 \\
\hline Fragility level 2 & 23.88 \\
\hline Fragility level 3 & 12.27 \\
\hline Fragility level 4 & 14.24 \\
\hline Objective financial knowledge (0-6) & $3.39(1.56)$ \\
\hline Subjective financial knowledge (1-7) & $5.24(1.26)$ \\
\hline \multicolumn{2}{|l|}{ Socio-demographic characteristics } \\
\hline Age (25-64) & $43.76(11.04)$ \\
\hline Female & 48.40 \\
\hline \multicolumn{2}{|l|}{ Race/ethnicity } \\
\hline Non-hispanic white & 72.67 \\
\hline Non-hispanic black & 10.04 \\
\hline Hispanic & 9.29 \\
\hline Non-hispanic other & 8.00 \\
\hline \multicolumn{2}{|l|}{ Education } \\
\hline$<=$ high school & 19.34 \\
\hline Some college & 25.01 \\
\hline College degree & 38.54 \\
\hline Post-graduate degree & 17.11 \\
\hline Homeowner & 66.15 \\
\hline \multicolumn{2}{|l|}{ Income } \\
\hline$\$ 25,000$ and less & 9.76 \\
\hline$\$ 25,000-\$ 35,000$ & 8.85 \\
\hline$\$ 35,000-\$ 50,000$ & 13.84 \\
\hline$\$ 50,000-\$ 75,000$ & 21.17 \\
\hline$\$ 75,000-\$ 100,000$ & 18.35 \\
\hline$\$ 100,000-\$ 150,000$ & 17.94 \\
\hline$\$ 150,000$ and higher & 10.09 \\
\hline Married & 57.17 \\
\hline Having dependent child & 48.91 \\
\hline \multicolumn{2}{|l|}{ Working status } \\
\hline Working full-time & 76.54 \\
\hline Working part-time & 11.38 \\
\hline Self-employed & 12.08 \\
\hline
\end{tabular}

$\mathrm{N}=10,748$. Unweighted. Sample restricted to non-retired adults aged 25-64 and who provided valid responses to all variables 


\section{Multivariate Results: Logistic Regression Analyses}

\section{DV1: Calculating Retirement Needs}

Table 2 presents regression results on calculating retirement needs. Respondents experiencing difficulties making ends meet were more likely to calculate retirement needs than those not experiencing difficulty. Specifically, compared to those who had no difficulty, those who had a high difficulty making ends meet had $89.7 \%$ higher odds of calculating retirement needs, and those who had somewhat difficulty making ends meet had $26 \%$ higher odds of calculating retirement needs. As the level of financial fragility increased, the likelihood of
Table 2 Logistic regression analysis of retirement need calculation, 2018 NFCS

\begin{tabular}{|c|c|c|c|c|c|}
\hline Variable & $\mathrm{B}$ & SE & $p$ & Sig & $\mathrm{e}^{\beta}$ (Odds ratio) \\
\hline \multicolumn{6}{|c|}{ Difficulty making ends meet (Ref: Not difficult) } \\
\hline Very difficult & 0.640 & 0.090 & 0.000 & $* * *$ & 1.897 \\
\hline Somewhat difficult & 0.231 & 0.057 & 0.000 & $* * *$ & 1.260 \\
\hline Perceived over-indebtedness & -0.018 & 0.012 & 0.123 & & 0.982 \\
\hline \multicolumn{6}{|c|}{ Financial fragility (Ref: level 1-Lowest) } \\
\hline Fragility level 2 & -0.464 & 0.058 & 0.000 & $* * *$ & 0.629 \\
\hline Fragility level 3 & -0.699 & 0.079 & 0.000 & $* * *$ & 0.497 \\
\hline Fragility level 4 & -0.862 & 0.083 & 0.000 & $* * *$ & 0.422 \\
\hline Objective financial knowledge & 0.188 & 0.016 & 0.000 & $* * *$ & 1.207 \\
\hline Subjective financial knowledge & 0.347 & 0.020 & 0.000 & $* * *$ & 1.414 \\
\hline \multicolumn{6}{|l|}{ Socio-demographic characteristics } \\
\hline Age & 0.004 & 0.002 & 0.097 & & 1.004 \\
\hline Female & -0.062 & 0.046 & 0.182 & & 0.940 \\
\hline \multicolumn{6}{|l|}{ Race/ethnicity (Ref: NH-White) } \\
\hline Non-hispanic Black & 0.310 & 0.082 & 0.000 & $* * *$ & 1.363 \\
\hline Hispanic & -0.089 & 0.081 & 0.270 & & 0.915 \\
\hline Non-Hispanic other & 0.096 & 0.089 & 0.283 & & 1.101 \\
\hline \multicolumn{6}{|l|}{ Education (Ref: $<=$ high school) } \\
\hline Some college & 0.329 & 0.068 & 0.000 & $* * *$ & 1.390 \\
\hline College degree & 0.362 & 0.064 & 0.000 & $* * *$ & 1.437 \\
\hline Post-graduate degree & 0.490 & 0.080 & 0.000 & $* * *$ & 1.632 \\
\hline Homeowner & 0.453 & 0.053 & 0.000 & $* * *$ & 1.573 \\
\hline \multicolumn{6}{|l|}{ Income (Ref: $\leq \$ 25,000)$} \\
\hline$\$ 25,000-\$ 35,000$ & 0.254 & 0.108 & 0.018 & $*$ & 1.289 \\
\hline$\$ 35,000-\$ 50,000$ & 0.540 & 0.099 & 0.000 & $* * *$ & 1.717 \\
\hline$\$ 50,000-\$ 75,000$ & 0.549 & 0.097 & 0.000 & $* * *$ & 1.731 \\
\hline$\$ 75,000-\$ 100,000$ & 0.822 & 0.104 & 0.000 & $* * *$ & 2.275 \\
\hline$\$ 100,000-\$ 150,000$ & 0.949 & 0.109 & 0.000 & $* * *$ & 2.584 \\
\hline$\$ 150,000$ and higher & 1.259 & 0.129 & 0.000 & $* * *$ & 3.523 \\
\hline Married & -0.053 & 0.052 & 0.310 & & 0.948 \\
\hline Having dependent child & -0.047 & 0.048 & 0.327 & & 0.954 \\
\hline \multicolumn{6}{|c|}{ Working status (Ref: working full-time) } \\
\hline Working part-time & -0.130 & 0.074 & 0.081 & & 0.878 \\
\hline Self-employed & -0.062 & 0.070 & 0.376 & & 0.940 \\
\hline State of residence & Included & & & & \\
\hline Constant & -3.187 & 0.255 & 0.000 & $* * *$ & NA \\
\hline Likelihood ratio Chi-square & 2485.140 & $\mathrm{df}=77$ & $\mathrm{p}=.000$ & & \\
\hline Pseudo $\mathrm{R}^{2}$ & 0.168 & & & & \\
\hline
\end{tabular}

Note. $N=10,748$. Unweighted. Sample restricted to non-retired adults aged $25-64$ and who provided valid responses to all variables

$* p<0.05 ; * * p<0.01 ; * * *<.001$ 
calculating retirement needs decreased gradually. Compared to those in the lowest level of financial fragility, those in the second, third, and forth levels showed $37.1 \%$, $50.3 \%$, and $57.8 \%$ decreases in odds of calculating retirement needs, respectively. Both objective and subjective financial knowledge were positively associated with the likelihood of calculating retirement needs. Providing an additional correct answer to the six objective financial knowledge questions was associated with $20.7 \%$ increase in the odds of calculating retirement needs, while a onepoint increase in the subjective financial knowledge was associated with $41.4 \%$ increase in the odds of calculating retirement needs. Black respondents were more likely than their White counterparts to calculate retirement needs. Educational attainment, being a homeowner, and the level of income showed positive associations with the likelihood of calculating retirement needs.

\section{DV2: Retirement Account Ownership (any type)}

Results from logistic regression on any type (i.e., through an employer or not through an employer) of retirement account ownership were presented in Table 3. The level of perceived over-indebtedness was associated positively with the likelihood of owning any retirement account. Specifically, a one-point increase in the perceived overindebtedness was associated with $3.5 \%$ increase in the odds of owning any type of retirement account. As the level of fragility increased, the likelihood of owning any type of retirement account decreased gradually. In particular, compared to those in the lowest level of financial fragility, those in the second, third, and forth levels showed $52 \%, 62.7 \%$, and $66.3 \%$ decreases in odds of owning any type of retirement account, respectively. Both objective and subjective knowledge were positively associated with the likelihood of owning any type of retirement plan. Providing an additional correct answer to the six objective financial knowledge questions was associated with $16.5 \%$ increase in the odds of owning a retirement account, while a one-point increase in the subjective financial knowledge was associated with $8.7 \%$ increase in the odds of owning a retirement account of any type. Furthermore, age and income levels showed positive associations with the likelihood of owning a retirement account. Being female, Black, a homeowner, and having a college degree or higher educational attainment increased the likelihood of owning retirement accounts. Compared to full-time workers, part-time workers and self-employed workers showed a lower likelihood of owning retirement accounts of any type.
DV3 and DV4: Retirement Account Through vs. Not-Through Employer

Table 4 shows additional logistic regression analysis on employer-sponsored and non-employer sponsored plans. There was no association between the difficulty of making ends meet and the ownership of employer-sponsored plans. Respondents who reported making ends meet was very difficult were more likely to own non-employer sponsored plans. More specifically, the odds of owning a nonemployer-sponsored retirement account of those who had a high difficulty making ends meet were 2.04 times higher than those who had no difficulty. The level of perceived overindebtedness was associated positively with the likelihood of owning employer-sponsored plans while associated negatively with the likelihood of owning non-employer-sponsored plans. In particular, a one-point increase in the perceived over-indebtedness was associated with 5.3\% increase in the odds of owning an employer-sponsored account but was associated with $6.3 \%$ decrease in the odds of owning an employer-sponsored account. The likelihood of owning employer-sponsored and non-employer sponsored retirement accounts decreased gradually as the level of fragility increased. In particular, compared to those in the lowest level of financial fragility, those in the second, third, and forth levels showed $39.9 \%, 55 \%$, and $57.7 \%$ decreases in odds of owning an employer-sponsored retirement account, respectively. Similarly, for non-employer-sponsored retirement account ownership, compared to those in the lowest level of financial fragility, those in the second, third, and forth levels showed $52.7 \%, 65.1 \%$, and $78.9 \%$ decreases in odds, respectively. Moreover, we observed positive associations between both objective and subjective financial knowledge with the likelihood of owning either employersponsored or non-employer sponsored retirement plans. The sociodemographic characteristics and state of residence were controlled in these regression analyses. Full results are available from the authors upon request.

\section{Additional Analyses by Generation}

Because retirement planning behavior varies substantially by age and generation (Munnell et al., 2006; Hira et al., 2009; Kim \& Kim, 2010; Yao \& Chen, 2017), we conducted additional logistic regression analyses by generations for the four dependent variables of interest. Following Pew Research Center's (2018) categorizations of generations, we grouped our sample into Millennials (Born 1981-1997), Gen-X (Born 1965-1980), and Boomers (Born 1946-1964).

Among the Millennial group, around 52\% reported having calculated retirement needs, $75 \%$ had any type of retirement 
Table 3 Logistic regression analysis of retirement account ownership (any type), 2018 NFCS

\begin{tabular}{|c|c|c|c|c|c|}
\hline Variable & $\mathrm{B}$ & SE & $p$ & Sig & $\mathrm{e}^{\beta}$ (Odds ratio) \\
\hline \multicolumn{6}{|c|}{ Difficulty making ends meet (Ref: not difficult) } \\
\hline Very difficult & -0.182 & 0.105 & 0.085 & & 0.834 \\
\hline Somewhat difficult & -0.104 & 0.074 & 0.160 & & 0.902 \\
\hline Perceived over-indebtedness & 0.034 & 0.015 & 0.025 & $*$ & 1.035 \\
\hline \multicolumn{6}{|c|}{ Financial fragility (Ref: level 1-Lowest) } \\
\hline Fragility level 2 & -0.733 & 0.082 & 0.000 & $* * *$ & 0.480 \\
\hline Fragility level 3 & -0.987 & 0.098 & 0.000 & $* * *$ & 0.373 \\
\hline Fragility level 4 & -1.087 & 0.100 & 0.000 & $* * *$ & 0.337 \\
\hline Objective financial knowledge & 0.153 & 0.021 & 0.000 & $* * *$ & 1.165 \\
\hline Subjective financial knowledge & 0.084 & 0.023 & 0.000 & $* * *$ & 1.087 \\
\hline \multicolumn{6}{|l|}{ Socio-demographic characteristics } \\
\hline Age & 0.007 & 0.003 & 0.014 & $*$ & 1.007 \\
\hline Female & 0.263 & 0.062 & 0.000 & $* * *$ & 1.301 \\
\hline \multicolumn{6}{|l|}{ Race/ethnicity (Ref: NH-White) } \\
\hline Non-Hispanic Black & 0.319 & 0.100 & 0.001 & $* *$ & 1.375 \\
\hline Hispanic & -0.021 & 0.101 & 0.837 & & 0.980 \\
\hline Non-Hispanic other & 0.141 & 0.121 & 0.246 & & 1.151 \\
\hline \multicolumn{6}{|l|}{ Education (Ref: $<=$ high school) } \\
\hline Some college & 0.046 & 0.079 & 0.559 & & 1.047 \\
\hline College degree & 0.369 & 0.079 & 0.000 & $* * *$ & 1.447 \\
\hline Post-graduate degree & 0.620 & 0.116 & 0.000 & $* * *$ & 1.859 \\
\hline Homeowner & 0.744 & 0.065 & 0.000 & $* * *$ & 2.104 \\
\hline \multicolumn{6}{|l|}{ Income (Ref: $\leq \$ 25,000)$} \\
\hline$\$ 25,000-\$ 35,000$ & 0.606 & 0.104 & 0.000 & $* * *$ & 1.833 \\
\hline$\$ 35,000-\$ 50,000$ & 1.038 & 0.099 & 0.000 & $* * *$ & 2.824 \\
\hline$\$ 50,000-\$ 75,000$ & 1.343 & 0.102 & 0.000 & $* * *$ & 3.832 \\
\hline$\$ 75,000-\$ 100,000$ & 2.019 & 0.126 & 0.000 & $* * *$ & 7.533 \\
\hline$\$ 100,000-\$ 150,000$ & 2.078 & 0.142 & 0.000 & $* * *$ & 7.992 \\
\hline$\$ 150,000$ and higher & 2.062 & 0.191 & 0.000 & $* * *$ & 7.860 \\
\hline Married & 0.320 & 0.066 & 0.000 & $* * *$ & 1.377 \\
\hline Having dependent child & -0.038 & 0.064 & 0.556 & & 0.963 \\
\hline \multicolumn{6}{|c|}{ Working status (Ref: working full-time) } \\
\hline Working part-time & -0.656 & 0.085 & 0.000 & $* * *$ & 0.519 \\
\hline Self-employed & -1.485 & 0.081 & 0.000 & $* * *$ & 0.226 \\
\hline State of residence & Included & & & & \\
\hline Constant & -1.309 & 0.309 & 0.000 & $* * *$ & NA \\
\hline Likelihood ratio Chi-square & 3462.510 & $\mathrm{df}=77$ & $\mathrm{p}=.000$ & & \\
\hline Pseudo $\mathrm{R}^{2}$ & 0.310 & & & & \\
\hline
\end{tabular}

Note. $N=10,748$. Unweighted. Sample restricted to non-retired adults aged 25-64 and who provided valid responses to all variables

${ }^{*} p<0.05 ; * * p<0.01 ; * * * p<.001$ account, $71 \%$ had employer-sponsored account(s), and 36\% had non-employer-sponsored account(s). About 39\% and $18 \%$ reported making ends meet was somewhat or very difficult. The average perceived over-indebtedness was 4.60 out of $7.44 \%$ of the Millennials reported having the lowest financial fragility level, while $16 \%$ reported having the highest level of financial fragility. Of all Gen-Xers, 53\% had calculated retirement needs, $79 \%$ had any type of retirement account, about $75 \%$ had employer-sponsored account(s), and about $38 \%$ had non-employer-sponsored account(s). The majority (54\%) had no difficulty making ends meet and about $36 \%$ experienced some difficulty. The average perceived over-indebtedness of Gen-Xers was 4.10 out of 7. Close to half of this generation had the lowest financial fragility level (47\%), and 15\% reported the highest level of financial fragility. Among the Baby Boomers, around 64\% 
Table 4 Logistic regression analysis of retirement account ownership (employer-sponsored and non-employer sponsored)

\begin{tabular}{|c|c|c|c|c|c|c|c|c|}
\hline & $\begin{array}{l}\text { Employer- } \\
\text { sponsored } \\
\text { plans }\end{array}$ & $\begin{array}{l}\text { Non-employer- } \\
\text { sponsored } \\
\text { plans }\end{array}$ & & & & & & \\
\hline Variable & $\mathrm{B}$ & SE & Sig & $\mathrm{e}^{\beta}$ (Odds ratio) & B & SE & Sig & $\mathrm{e}^{\beta}$ (Odds ratio) \\
\hline \multicolumn{9}{|c|}{$\begin{array}{l}\text { Difficulty making ends meet (Ref: not } \\
\text { difficult) }\end{array}$} \\
\hline Very difficult & -0.091 & 0.101 & & 0.913 & 0.710 & 0.096 & $* * *$ & 2.035 \\
\hline Somewhat difficult & -0.084 & 0.069 & & 0.919 & 0.007 & 0.060 & & 1.007 \\
\hline Perceived over-indebtedness & 0.052 & 0.014 & $* * *$ & 1.053 & -0.065 & 0.012 & $* * *$ & 0.937 \\
\hline \multicolumn{9}{|l|}{$\begin{array}{l}\text { Financial fragility (Ref: level 1-Low- } \\
\text { est) }\end{array}$} \\
\hline Fragility level 2 & -0.508 & 0.074 & $* * *$ & 0.601 & -0.748 & 0.059 & $* * *$ & 0.473 \\
\hline Fragility level 3 & -0.798 & 0.092 & $* * *$ & 0.450 & -1.052 & 0.089 & $* * *$ & 0.349 \\
\hline Fragility level 4 & -0.861 & 0.094 & $* * *$ & 0.423 & -1.556 & 0.101 & $* * *$ & 0.211 \\
\hline Objective financial knowledge & 0.119 & 0.020 & $* * *$ & 1.126 & 0.103 & 0.017 & $* * *$ & 1.109 \\
\hline Subjective financial knowledge & 0.074 & 0.022 & $* *$ & 1.077 & 0.283 & 0.022 & $* * *$ & 1.327 \\
\hline Sociodemographic characteristics & Included & & & & Included & & & \\
\hline State of residence & Included & & & & Included & & & \\
\hline Constant & -1.290 & 0.297 & $* * *$ & NA & -3.976 & 0.280 & $* * *$ & NA \\
\hline Likelihood ratio Chi-square & 3434.190 & $\mathrm{df}=77$ & $\mathrm{p}=.000$ & & 3089.060 & $\mathrm{df}=77$ & $\mathrm{p}=.000$ & \\
\hline Pseudo $\mathrm{R}^{2}$ & 0.280 & & & & 0.213 & & & \\
\hline
\end{tabular}

Note. $\mathrm{N}=10,748$. Unweighted. Sample restricted to non-retired adults aged $25-64$ and who provided valid responses to all variables. Sociodemographic variables are the same as Tables 2 and 3

$* p<0.05 ; * * p<0.01 ; * * * p<.001$

had calculated retirement needs, $84 \%$ had any type of retirement account, $77 \%$ had employer-sponsored account(s), and $52 \%$ had non-employer-sponsored account(s). Over half $(66 \%)$ had no difficulty making ends meet and only about $5 \%$ reported making ends meet was very difficult. The majority (62\%) had the lowest level of financial fragility and about $8 \%$ and $10 \%$ reported having levels 3 and 4 of financial fragility respectively (Table 5).

Table 6 presents the regression results for retirement need calculation, any retirement account ownership, employersponsored account ownership, and non-employer-sponsored account ownership across three generations. Among the three financial hardship measures, financial fragility showed consistent patterns across the three generations, whereas difficulty making ends meet and the perceived over-indebtedness showed different associations with the four dependent variables by generation.

In particular, Millennials and Boomers reporting that making ends meet was somewhat or very difficult were more likely to calculate retirement needs as compared to those who did not have any difficulty. However, among GenXers, only those reporting making ends meet was somewhat difficult were more likely to calculate retirement needs.
Moreover, perceived over-indebtedness was negatively associated with the likelihood of calculating retirement needs only among the Boomers. In terms of retirement account ownership, the negative association between very difficulty making ends meet and owning any retirement account was only found among Gen-Xers.

When examining employer-sponsored and non-employersponsored retirement account ownership separately by generation, we also observed generational differences in the roles of the ability to make ends meet and the perceived over-indebtedness. Specifically, Millennials reporting high difficulty in making ends meet was positively associated with the likelihood of owning both employer and non-employer sponsored retirement accounts when compared to their counterparts. However, this relationship was found to be negative among Gen-Xers and Boomers for their employer-sponsored account ownership. We also found that the perceived overindebtedness was positively associated with the likelihood of having employer-sponsored retirement accounts of GenXers. Lastly, there was a negative association between the perceived over-indebtedness and the likelihood of owning non-employer-sponsored retirement accounts among the Gen-X and Boomer generations. 
Table 5 Descriptive statistics of analytic sample across generations, 2018 NFCS

\begin{tabular}{lllc}
\hline Variable & Millennials & Generation Xers & Boomers \\
\hline Retirement planning (\%) & & & \\
$\quad$ Calculating retirement needs & 51.65 & 52.50 & 63.66 \\
Having retirement account (any type) & 74.59 & 78.82 & 83.61 \\
Retirement account (through employer) & 71.15 & 75.03 & 77.38 \\
Retirement account (not through employer) & 36.01 & 38.06 & 51.59 \\
Difficulty making ends meet (\%) & & & \\
Not difficult & 42.99 & 54.10 & 66.34 \\
Somewhat difficult & 39.29 & 36.26 & 28.54 \\
Very difficult & 17.71 & 9.64 & 5.12 \\
Perceived over-indebtedness (1-7) & $4.60(2.28)$ & $4.10(2.28)$ & $3.28(2.20)$ \\
Financial fragility (\%) & & & 61.90 \\
Fragility level 1 & 43.95 & 47.09 & 19.76 \\
Fragility level 2 & 25.71 & 24.79 & 8.18 \\
Fragility level 3 & 14.46 & 12.84 & 10.16 \\
Fragility level 4 & 15.88 & 15.28 & \\
\hline
\end{tabular}

Unweighted

\section{Discussion and Implication}

This study examined the association between financial hardship and retirement planning behavior. Using the 2018 NFCS dataset, we found that high difficulty making ends meet was positively associated with the likelihood of calculating retirement needs, which was the opposite of H1-1. Further investigation on the positive relationship found in the current study between the difficulty making ends meet and the tendency to calculate retirement needs is needed. One possible explanation is that those who have difficulty covering monthly expenses could be more concerned about their long-term financial security. Financial capability is key for financial stability and security (Sherraden et al., 2015) and the inability to make ends meet could indicate low financial capability to reach long-term financial security. We also found that the increase in financial fragility levels was negatively associated with the likelihood of calculating retirement needs, which supported H1-3. This is consistent with previous literature that found saving for long-term goals can be challenging for those with current financial difficulties (Schreiner \& Sharraden, 2007).

When examining retirement account ownership (of any type), the results showed that the perceived over-indebtedness was positively related to the likelihood of owning a retirement account, opposite to H2-2. However, perceived over-indebtedness was negatively related to the likelihood of owning a non-employer-sponsored account. These conflicting results can be explained by the ability to take out a loan. Lenders are more likely to lend to someone with a stable job that comes with an employer-sponsored retirement plan. The borrower might not be contributing to the plan and cannot afford to create a non-employer-sponsored plan due to perceived over-indebtedness. This can be one explanation for the positive relationship found between over-indebtedness and owning any retirement account. In addition, the increase in financial fragility levels was negatively associated with the likelihood of owning any retirement account, supporting H2-3. When examining employer-sponsored and non-employer sponsored retirement account ownership separately, we found varying associations with difficulty making ends meet and perceived over-indebtedness. Particularly, those reporting making ends meet was very difficult were more likely to hold non-employer sponsored retirement plans. Individuals with higher perceived over-indebtedness were more likely to own an employer-sponsored retirement account but less likely to own a non-employer sponsored account. Financial fragility showed a negative relationship with the likelihood of calculating retirement needs and having a retirement account of any type or established through or not-through an employer. Furthermore, the results showed that while financial fragility showed consistent patterns across generations, the difficulty of making ends meet and the perceived over-indebtedness showed different associations with retirement planning behavior across generations.

This study has some limitations to be noted. First, given the cross-sectional structure of the NFCS dataset, we were unable to make a causal inference between financial hardship and retirement planning behaviors. The use of a longitudinal dataset may allow researchers to address a possible causal inference using an appropriate statistical method. Second, the NFCS dataset does not collect details of balance sheet information. For example, we used the ownership of employer or non-employer sponsored retirement plans, but the accumulated amount of the retirement plan is not available. Even though we used homeownership as a proxy 


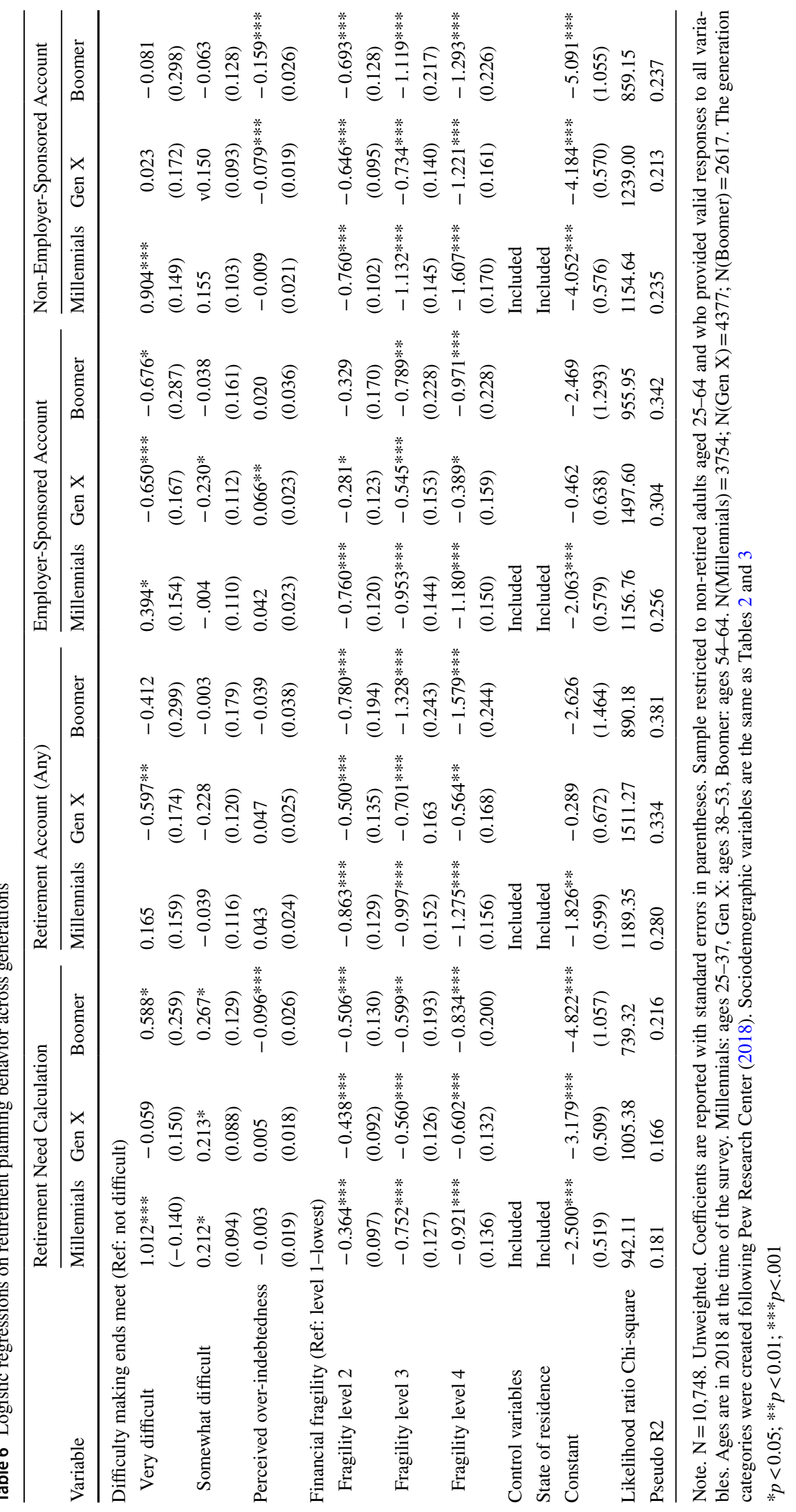


for wealth, but this could be a limitation. In addition, insurance coverage could influence financial fragility by reducing the need for emergency funds. Finally, questions as a proxy for financial hardship are based on the respondent's selfassessment about their financial indebtedness and hardship, which may be inconsistent with the actual level of financial hardship. Future studies may revisit this issue to construct a comprehensive measure to incorporate perceived and actual financial hardship levels.

Planning for retirement to reach financial security has become more critical for individuals and households as employers have shifted to DC plans. However, we found that only about $55 \%$ sample reported having calculated retirement needs, and even among non-retired older individuals (i.e., Gen-Xers and Boomers), only about 53 to $64 \%$ had ever calculated their retirement needs. The percentage was the lowest for Millennials with only $52 \%$ having calculated retirement needs. These findings are concerning because the lack of planning ahead for retirement has not been improved in the past decade, as shown in the Lusardi (2011) study using the 2009 wave of NFCS. As $80 \%$ of our sample reported, simply owning retirement accounts does not guarantee adequate savings for retirement. Therefore, it is urgent for policy makers to promote and increase awareness of retirement planning's significance and develop retirement planning education programs and tools. Previous studies have suggested that more effective and integrated approaches, such as peer-to-peer engagements over social media, are needed to engage Millennials due to their low awareness of their lack of financial knowledge and but high confidence in financial management ability (de Bassa Scheresberg et al., 2014). Persuasive communication approaches are also proposed based on psychological theories, such as increasing perceived savings ability based on self-efficacy and motivational theories, increasing actual ability to save by enhancing internal willpower and external structural changes (i.e., automatic enrollment) to promote retirement savings (e.g., Wiener \& Doescher, 2008).

The current study provides new insight into retirement planning behaviors by examining its relationships with multiple aspects of financial hardship, including the ability to making ends meet, perceived over-indebtedness, and financial fragility. We found that those who found it very hard to make ends meet were more likely to own non-employer sponsored retirement plans. However, without enough income or liquid savings to cover monthly expenses, these households may not be able to make contributions. Interestingly, we found that the experience of somewhat or high difficulty making ends meet was more likely to push people to engage in retirement calculation behavior. Retirement needs calculators are easily accessible from reputable brokerage houses and consumer advocacy websites. Governmental organizations such as the Social Security Administration and the Internal Revenue Service could offer these tools to consumers. However, financial hardship may prevent contributing to a retirement account. These findings may indicate a potential dilemma among those struggling to make ends meet.

That said, policy implications include encouraging having emergency funds through legislative action. The Saver's Credit has incentivized retirement savings by allowing individuals with moderate-income to reduce tax liability dollarfor-dollar up to $\$ 2000$ by contributing to a retirement plan. However, only $38 \%$ of workers are aware of the credit, and that number goes down with less-educated, lower-income, and those over the age of 37 (Transamerica Center for Retirement Studies, 2020). Less than 6\% of eligible filers claimed the credit (AARP, 2017); automatically creating a Saver's IRA account at tax filing that took advantage of the credit with opt-out ability would increase retirement savings. Increasing awareness could boost that 6 to $100 \%$. For taxpayers receiving a refund, the ability to defer a portion of the refund into a Treasury-held account that accumulates interest and is later transferred to the filer's direct deposit would create an emergency fund. This idea was proposed in the Refund to Rainy Day Savings Act, which was introduced to Congress in 2019 and is currently under review by Committee (S.1018, 2019).

Policy considerations to ease over-indebtedness exist in the form of public service loan forgiveness programs. However, less than $2 \%$ of applicants have had debt discharged (U.S. Department of Education, 2020). Discussions are underway to forgive portions of student loans, but no additional legislation has been passed. The perceived overindebtedness as found in the current study was negatively associated with pre-retired Baby Boomers' retirement calculation and non-employer sponsored retirement account ownership.

This research is especially salient given the $17.3 \%$ peak in the poverty rate in September 2020 in the midst of the global COVID-19 pandemic (Parolin et al., 2020). Families are struggling financially in the United States and government policy designed to ease the financial burdens can only go so far. However, following the development and distribution of vaccines, the Dow Jones Industrial Average is near an all-time high at 33,874.36 on May 4, 2021. Unemployment has dropped to 6\% in March 2021 (Bureau of Labor Statistics 2021). With so many families recently experiencing financial hardship, budgeting and taking steps to save for the future might be the next logical step. This research provides a greater understanding of the relationship between financial hardship and retirement planning. This will continue to be an integral part of the long-term well-being of families. Future studies can continue investigating this topic by examining, for example, how can financially fragile families be encouraged to save for their future? 


\section{Declarations}

Conflict of interest The authors declare that they have no conflict of interest.

Research Involving Human and Animal Participants This article does not contain any studies with human participants or animals performed by any of the authors.

\section{References}

AARP. (2017). Improving the saver's credit for low and moderate income workers. https://www.aarp.org/content/dam/aarp/ppi/ 2017/09/improving-the-savers-credit-for-low-and-moderateincome-workers.pdf

Ando, A., \& Modigliani, F. (1963). The" life cycle" hypothesis of saving: Aggregate implications and tests. The American Economic Review, 53(1), 55-84.

Babiarz, P., \& Robb, C. A. (2014). Financial literacy and emergency saving. Journal of Family and Economic Issues, 35(1), 40-50.

Baek, E., \& DeVaney, S. A. (2010). How do families manage their economic hardship? Family Relations, 59(4), 358-368.

Bengen, W. P. (1994). Determining withdrawal rates using historical data. Journal of Financial Planning, 7(4), 171-180.

Bernanke, B., \& Gertler, M. (1990). Financial fragility and economic performance. The Quarterly Journal of Economics, 105(1), 87-114.

Bernartzi, S., \& Thaler, R. (2007). Heuristics and biases in retirement savings behavior. Journal of Economic Perspectives, 21(3), 81-104. https://doi.org/10.1257/jep.21.3.81

Cilluffo, A. (2017). Five facts about student loans. Pew Research Center. http://www.pewresearch.org/fact-tank/2017/08/24/5-factsabout-student-loans/.

Consumer Financial Protection Bureau. (2019). What is a debt-toincome ratio? Why is the $43 \%$ debt-to-income ratio important? https://www.consumerfinance.gov/ask-cfpb/what-is-a-debtto-income-ratio-why-is-the-43-debt-to-income-ratio-impor tant-en-1791/

de Bassa Scheresberg, C., Lusardi, A., \& Yakoboski, P. J. (2014). College-educated millennials: An overview of their personal finances. TIAA-CREF Institute and the Global Financial Literacy Excellence Center (February), 1-38. https://millennialmoney. com/wp-content/uploads/2015/09/millennials_personal_finances feb2014.pdf

Despard, M. R., Friedline, T., \& Birkenmaier, J. (2018). Policy Recommendations for Helping US Households Build Emergency Savings.

Despard, M. R., Friedline, T., \& Martin-West, S. (2020). Why do households lack emergency savings? The role of financial capability. Journal of Family and Economic Issues. https://doi.org/10. 1007/s10834-020-09679-8

Dong, X. S., Wang, X., Ringen, K., \& Sokas, R. (2017). Baby boomers in the United States: Factors associated with working longer and delaying retirement. American Journal of Industrial Medicine, 60(4), 315-328.

Dushi, I., Iams, H. M., \& Trenkamp, B. (2017). The importance of social security benefits to the income of the aged population. Social Security Bulletin, 77, 1.

EBRI. (2020). Retirement Confidence Survey Summary Report. https:// www.ebri.org/docs/default-source/rcs/2020-rcs/2020-rcs-summa ry-report.pdf?sfvrsn=84bc3d2f_7
Experian. (2021). What is a credit utilization rate? https://www.exper ian.com/blogs/ask-experian/credit-education/score-basics/creditutilization-rate/

FINRA. (2018). The State of U.S. Financial Capability: The 2018 National Financial Capability Study. https://www.usfinancialcapa bility.org/downloads/NFCS_2018_Report_Natl_Findings.pdf.

Fitch, C., Hamilton, S., Bassett, P., \& Davey, R. (2011). The relationship between personal debt and mental health: A systematic review. Mental Health Review Journal, 16(4), 153-166.

Gillen, M., \& Heath, C. J. (2014). Women's timing of receipt of Social Security retirement benefits. Journal of Family and Economic Issues, 35(3), 362-365. https://doi.org/10.1007/ s10834-013-9374-z

Gjertson, L. (2016). Emergency saving and household hardship. Journal of Family and Economic Issues, 37(1), 1-17.

Hasler, A., Lusardi, A., \& Oggero, N. (2018). Financial fragility in the US: Evidence and Implications. GFLEC Research Paper. https:// gflec.org/wp-content/uploads/2018/04/Financial-Fragility-Resea rch-Paper-04-16-2018-Final.pdf

Hiltonsmith, R. (2013). At what cost? How student debt reduces lifetime wealth (report). New York: Demos. http://www.demos.org/ sites/default/files/publications/AtWhatCostFinal_Demos.p

Hira, T. K., Rock, W. L., \& Loibl, C. (2009). Determinants of retirement planning behaviour and differences by age. International Journal of Consumer Studies, 33(3), 293-301. https://doi.org/10. 1111/j.1470-6431.2009.00742.x

Kim, H., \& Kim, J. (2010). Information search for retirement plans among financially distressed consumers. Journal of Family and Economic Issues, 31(1), 51-62. https://doi.org/10.1007/ s10834-009-9179-2

Kim, J., \& Chatterjee, S. (2019). student loans, health, and life satisfaction of US households: Evidence from a panel study. Journal of Family and Economic Issues, 40, 36-50. https://doi.org/10.1007/ s10834-018-9594-3

Kim, K. T., \& Hanna, S. D. (2015). Does financial sophistication matter in retirement preparedness? Journal of Personal Finance, 14(2), $9-20$

Lempers, J. D., Clark-Lempers, D., \& Simons, R. L. (1989). Economic hardship, parenting, and distress in adolescence. Child Development, 25-39.

Lusardi, A. (2011). Americans' financial capability (NBER working paper, No. w17103). National Bureau of Economic Research. http://www.nber.org/papers/w17103

Lusardi, A., \& Mitchell, O. S. (2017). How ordinary consumers make complex economic decisions: Financial literacy and retirement readiness. Quarterly Journal of Finance, 7(03), 1750008.

Lusardi, A., Schneider, D. J., \& Tufano, P. (2011). Financially fragile households: Evidence and implications (NBER working paper, No. w17072). National Bureau of Economic Research. http:// www.nber.org/papers/w17072

Munnell, A. H., Webb, A., \& Delorme, L. (2006). A new national retirement risk index. Issue in Brief, 48 .

Modigliani, F., \& Cao, S. L. (2004). The Chinese saving puzzle and the life-cycle hypothesis. Journal of Economic Literature, 42(1), $145-170$.

Park, N., Heo, W., Ruiz-Menjivar, J., \& Grable, J. E. (2017). Financial hardship, social support, and perceived stress. Journal of Financial Counseling and Planning, 28(2), 322-332.

Parolin, Z., Curran, M., Matsudaira, J., Waldofogel, J., \& Wimer, C., (2020). Monthly poverty rates in the United States during the COVID-19 pandemic. Poverty and Social Policy Working Paper. https://static1.squarespace.com/static/5743308460b5e922a25a 6dc7/t/5f87c59e4cd0011 fabd38973/1602733471158/COVIDProjecting-Poverty-Monthly-CPSP-2020.pdf 
Pension Benefit Guaranty Corporation (2019). Projections Report. https://www.pbgc.gov/sites/default/files/fy-2019-projectionsreport.pdf

Pew Charitable Trusts. (2017). Are American families becoming more financially resilient? Changing household balance sheets and the effects of financial shocks (Issue Brief). https://www.pewtrusts. org/ /media/assets/2017/04/financialshocks_brief.pdf

Pew Research Center. (2018). Comparing millennials to other generations. https://www.pewresearch.org/interactives/how-gener ations-compare/

PwC. (2020). Employee Financial Wellness Survey: 2020 COVID19 update. https://www.pwc.com/us/en/industries/private-compa ny-services/images/pwc-9th-annual-employee-financial-welln ess-survey-2020.pdf

Pfau, W. D. (2011). Safe savings rates: A new approach to retirement planning over the lifecycle. Journal of Financial Planning, 24(5)

Poterba, J. M. (2000). Stock market wealth and consumption. Journal of Economic Perspectives, 14(2), 99-118.

Refund to Rainy Day Savings Act, S1018, 116th Cong. (2019). https:// www.congress.gov/bill/116th-congress/senate-bill/1018/text

Romm, A. T. (2015). The effect of retirement date expectations on pre-retirement wealth accumulation: The role of gender and bargaining power in married US households. Journal of Family and Economic Issues, 36(4), 593-605. https://doi.org/10.1007/ s10834-014-9413-4

Ross, C. E., \& Mirowsky, J. (1999). Refining the association between education and health: The effects of quantity, credential, and selectivity. Demography, 36(4), 445-460.

Schreiner, M., \& Sherraden, M. W. (2007). Can the poor save?: Saving $\&$ asset building in individual development accounts. Transaction Publishers.

Semega, J., Kollar, M., Shirder, E. A, \& Creamer, J. (2020) Income and poverty in the United States: 2019. Report Number P60-70. U.S. Census Bureau. https://www.census.gov/library/publicatio ns/2020/demo/p60-270.html

Sharpe, D. L. (2020). Reinventing retirement. Journal of Family and Economic Issues. https://doi.org/10.1007/s10834-020-09696-7

Sherraden, M. S., Huang, J., Frey, J. J., Birkenmaier, J., Callahan, C., Clancy, M. M., \& Sherraden, M. (2015). Financial capability and asset building for all. American Academy of Social Work and
Social Welfare, 1-29. https://grandchallengesforsocialwork.org/ wp-content/uploads/2016/01/WP13-with-cover.pdf

Short, K. (2003). Material and financial hardship and alternative poverty measures. In 163rd Annual Meeting of the American Statistical Association, San Francisco, California (pp. 1-34).

Sobolewski, J. M., \& Amato, P. R. (2005). Economic hardship in the family of origin and children's psychological well-being in adulthood. Journal of Marriage and Family, 67(1), 141-156.

Social Security Administration. (2020). Fact sheet. https://www.ssa. gov/news/press/factsheets/basicfact-alt.pdf

Transamerica Center for Retirement Studies. (2020). A compendium of findings about US workers, $19^{\text {th }}$ annual transamerica retirement survey, 2019. https://transamericacenter.org/tools-and-resources/ saver's-credit/savers-credit-awareness-infographic

Tufano, P., \& Lusardi, A. (2009). Debt literacy, financial experiences, and overindebtedness. National Bureau of Economic Research.

U.S. Bureau of Labor Statistics. (2020). National Compensation Survey, Latest Numbers. https://bls.gov/ncs/ebs/

U.S. Bureau of Labor Statistics. (2021). Current Employment Statistics. https://bls.gov/ncs

U.S. Census Bureau. (2020). Household pulse Survey Interactive Tool. https://www.census.gov/data-tools/demo/hhp/\#/?measures=FIR

U.S. Department of Education. (2020). Public Service Loan Forgiveness Data. https://studentaid.gov/data-center/student/loan-forgi veness/pslf-data

Van Rooij, M. C., Lusardi, A., \& Alessie, R. J. (2012). Financial literacy, retirement planning and household wealth. The Economic Journal, 122(560), 449-478.

Wells Fargo (2016). 2016 Wells Fargo Millennial Study. https://stati c1.squarespace.com/static/53068354e4b083d9ce6ab0da/t/58064 ace46c3c4a864a63b24/1476807375572/14845-2016-millennialretirement-study.pdf

Wiener, J., \& Doescher, T. (2008). A framework for promoting retirement savings. Journal of Consumer Affairs, 42(2), 137-164.

Yao, R., \& Cheng, G. (2017). Millennials' retirement saving behavior: Account ownership and balance. Family and Consumer Sciences Research Journal, 46(2), 110-128.

Publisher's Note Springer Nature remains neutral with regard to jurisdictional claims in published maps and institutional affiliations. 